Croatian Journal of Education

Vol.20; No.4/2018, pages: 1299-1325

Original research paper

Paper submitted: 22 ${ }^{\text {nd }}$ March 2018

Paper accepted: $10^{\text {th }}$ May 2018 https://doi.org/10.15516/cje.v20i4.3143

\title{
What Drives the Perception of School Principals as Professional Managers in Small European Countries? The Case of Croatia
}

\author{
Nikša Alfirević ${ }^{1}$ Dijana Vican² and Jurica Pavičić ${ }^{3}$ \\ 'University of Split, Faculty of Economics, Business and Tourism \\ ${ }^{2}$ University of Zadar, Department of Pedagogy \\ ${ }^{3}$ University of Zagreb, Faculty of Economics and Business
}

\section{Abstract}

In this study, the authors discuss the educational and social factors that contribute to the perception of school principals as an independent managerial profession. Empirical results are based on a household survey, nationally representative of the Republic of Croatia as a small European country involved in a comprehensive educational reform. The empirical results indicate that trust in individual social actors relevant for education and the public perception of school effectiveness can serve as predictors of the public assessment of principalship as a profession. Potential implications for further research and policy development in small European countries are suggested. The proposed policy interventions emphasize institutional capacity building and an attempt to achieve a positive feedback loop by strengthening mutual links between the development of local resources and the communication of positive local narratives.

Key words: Croatia; educational management; predictors; profession; school principals.

\section{Introduction}

The research question of this study is related to the identification and empirical testing of the factors driving the public perception of school principals as a managerial profession in Croatia. Since the development of professionalized and distributed educational leadership contributes to the effectiveness of educational systems (OECD, 2016), involving relevant public (stakeholders) into this process could be of significant value for Croatian education. 
The professionalization of school principals is of great importance for the success of national educational systems (Pont, Nusche, \& Moorman, 2008), which further leads to tangible outcomes in economic development and the competitiveness of national economies (Hanushek \& Woessmann, 2010). The Croatian education policy has not recognized the imperative of decentralizing school governance and decoupling it from political and administrative structures. Although different initiatives had been developed for more than twenty years, national recognition of school principals as an independent managerial profession was postponed multiple times, with the latest deadline for principal professionalization set for the year 2021. Furthermore, the local knowledge base related to educational management and leadership theory is also limited (Vican, Alfirević, \& Relja, 2016).

Successful 'grassroots' activities have emerged, contributing to the development of school management and leadership in Croatia. In the 2015-2017 period, a mid-sized Croatian public university was able to attract significant EU funding and develop occupational standards for educational managers/leaders, as well as to set up a oneyear post-graduate program for educational leadership. Educational researchers and policy actors in the region of South-East Europe (SEE) could be interested in such a case of good educational practice, although a systemic approach should be the preferred route in the development of educational leadership. One such system is operating in Slovenia, which has introduced principal occupational standards and developed formal leadership qualifications as early as 1995 (Sentočnik \& Rupar, 2009).

As other SEE countries have done even less when it comes to the development of professional educational managers and their occupational standards, results of this study could be relevant on the regional level and informative for educational policies in other small European countries. This might especially be the case with countries striving to implement educational reforms in accordance with the recommendations of transnational organizations, which include the decentralization of educational governance and the professionalization of school principals (see, e.g. OECD, 2016; Pont, Nusche, \& Moorman, 2008).

In addition, Burstein (1998) calls on sociologists to examine public opinion and its relationship to public policies, which has not happened in scholarly literature, at least in the case of small European countries. Existing literature on this relationship is well established and demonstrates a high level of impact on public opinion, especially when it comes to salient issues (Burstein, 2003; Page \& Shapiro, 1983). In the case of Croatia, the public opinion - media influence - public policy triangle seems to have been ignored even by social scientists, who seem to perceive it as a matter of 'practical politics', rather than scientific discourse, although Cook, Tyler, Goetz, Gordon, Protess, Leff, and Molotch (1983) emphasize the media practices of agenda setting as significant for public opinion and policy-making. Simultaneously, all aspects of the educational reform are an especially salient and newsworthy issue for the Croatian public. 


\section{Review of Previous Studies}

The development of educational professionals in the reform context is not a novel research topic. In the 1990s, models of the professional development of teachers were considered to be a component of the overall reform initiatives. It was recommended that traditional teacher training be reconsidered in line with the broader reform agenda (Little, 1993). Alfirević, Pavičić, and Relja (2016) have applied a similar approach to principal professionalization: namely, the authors advocate the use of training and support tools adjusted to the requirements of contemporary pedagogy and the national educational reform agenda. Such an alignment is important because, as Heck and Hallinger (2005) warn, educational researchers, practitioners and policy actors who often share the same interests and objectives, nevertheless perceive and frame those same interests and objectives in different ways, with little mutual understanding.

The topic of this paper, i.e. public opinion on principalship as a profession, can be conceptualized in terms of stakeholders' attitudes. Those stakeholders can also be conceptualized in terms of publics (Warner, 2002). This notion, considered to be the keystone of public relations theory and practice (Grunig \& Hunt, 1984), has rarely been used in educational practice and/or applied to educational constructs/processes. On the other hand, the logic of managing multiple publics and their expectations has become a relevant part of educational research, as applied to analysing stakeholders and managing stakeholder relationships, especially in the field of higher education (see, e.g. Cho \& Palmer, 2013; Jongbloed, Enders, \& Salerno, 2008; etc.).

Our intention is to apply the logic(s) of public relations and stakeholder management research to educational management and leadership, as one of the fields of mainstream educational policy. We believe that well-balanced policies could be formulated and implemented by understanding and addressing stakeholders' (publics') expectations, as empirically demonstrated in the case of higher education in Croatia (Pavičić, Alfirević, \& Mihanović, 2009).

Optimal policy should be achieved by balancing relevant stakeholders' (i.e. publics') expectations, in analogy with research on nonprofit organizations' performance. Namely, complexity and diversity, which characterizes both the public policy arena as well as the landscape of non-profit organizations, requires an inherent orientation toward multiple stakeholders/constituencies/publics (Padanyi \& Gainer, 2004). While 'juggling' multiple social incentives and requirements, non-profit managers need to achieve a socially constructed consensus of personal and organizational effectiveness (Herman \& Renz, 1997). Even when social constructionism is acknowledged by recognizing performance, there is usually a wide consensus of techniques and managerial approaches, considered by a range of publics as contemporary and relevant for the overall social context. Their usage is considered to differentiate more effective from less effective organizations (Herman \& Renz, 1998) and define the core perception of what represents organizational effectiveness in theory and managerial practice (Herman \& Renz, 2008). 
Along the same lines, policy issues should be decided upon by taking into consideration the most significant predictors of publics' perceptions and expectations. In this way, limitations inherent to the idea of unrestricted use of benchmarking (i.e. identifying the world's best practices and implementing them with smaller or greater adjustments of the national educational system and its social context), seem to be overcome. As indicated by Glatter \& Kydd (2003), the 'best' practices which emerge from contexts with different social (and other) characteristics, cannot be 'automatically' applied everywhere, especially if the policy expectations of the local publics are ignored.

This is why we advocate a contextualized approach to the identification of 'good' educational practices (as opposed to the 'best' ones) and their implementation. In this process, one should utilize existing drivers of the publics' perceptions and seek a balanced approach to the socially constructed consensus of what represents the overall interest' in developing a country's educational system. Through analogy with the recommendations emerging from research on non-profit organizations' performance, the effective policy-maker (or even the policy-influencer) should be aware of such socially embedded drivers of policy success - to use a sociological term, originally introduced by Granovetter (1985).

If the overall public policy arena is considered, the paradox of accepting the 'Europeanisation' of the policy process only in nominal terms, so as to receive the status of a European member state and/or financial assistance from EU funds, could also be addressed by our approach. The entire 'Europeanisation' approach to public policy (Radaelli, 2003), as implemented by countries applying for EU membership (or which have recently joined the EU), could be better understood and contextualized by looking into the policy constraints imposed by the local/regional publics. This is certainly a more honest alternative to considering those countries as being (more or less) mature enough to adjust themselves to the 'best' (European or other transnational) practices/benchmarks.

\section{Methodology \\ Population and Sample}

This research studies the population of the Republic of Croatia, and has been created to represent it on the household level. We have created a weighted, nationally representative sample of Croatian households by using the publicly available phone directory of the incumbent telecommunications operator as a sampling frame. By using a Computer-Aided Telephone Interviewing (CATI) software package, supporting the probabilistic sampling, 591 households were randomly selected. In order to achieve national representation on the household level, the sample has been weighted by using the criteria of age, gender, education and geographical location, with the coefficients computed from the results of the previous census in the Republic of Croatia. Results were entered, coded and analysed using the SPSS statistical analysis package. The obvious limitation of the public opinion approach used for sampling is related to the 
nature of the research results, which reflect the public perception of the constructs measured. Nevertheless, such an approach could prove useful for public policy actors in small European countries, who would like to assess the importance of educational policy stakeholders and the impact of their perceptions on the policy processes.

\section{Constructs, Measurement and Research Instrument}

Acknowledging multiple studies in the field of international educational benchmarking, especially the OECD PISA and its influence on educational policy (Breakspear, 2012; Creemers, 2006; Grek, 2009), the relative position of a country in international educational benchmarking studies and their interpretation by the general public will be considered as a relative predictor of principals' professionalization.

From a sociological point of view, social capital could be important as well. Measuring social capital with the level of public trust in institutions and individual actors relevant for education will be further discussed in this section of the paper.

Since the school effectiveness construct has been linked to school management and leadership multiple times (Hallinger \& Heck, 1998), the last potential factor has been identified in terms of the public perception of school effectiveness. Nevertheless, we are interested in reversing the traditional assumptions to see if there is public acknowledgement (consensus) of school effectiveness, as caused by a body of well-received managerial and leadership practices, with a focus on principal professionalization and managerial status.

Three control variables were also employed, including the respondents' gender, their level of education (with special emphasis on the formal higher education degree), and the status of a parent of under-aged children living in the same household.

The perception of the relative position in international educational benchmarking proved to be an especially difficult construct to measure. We avoided measures based on actual benchmarking rankings. This decision is supported by our previous research results related to the OECD PISA study (Vican, Alfirević, \& Pavičić, 2017), which point to the existence of a rather sizable gap in comparisons between actual educational benchmarking results and their public perception in Croatia. In order to make the assessment as 'respondent-friendly' as possible, we used three subsequent comparisons of the Croatian educational system to the following categories: the most developed EU member states, other EU member states, and small states in the South-East European (SEE) region. The categories were loosely based on a review of theory on educational management and leadership, and their specific features in the SEE region (Alfirević, Burušić, Pavičić, \& Relja, 2016).

The general public trust in political and legal institutions is emphasized as a major source of social capital (Rothstein \& Stolle, 2008). Nevertheless, measurement of trust in institutions, easily recognized on the community level, is also a complex task. Following a recently published study on the differences in perceptions related to social capital in Croatia and Serbia on the level of local communities (Pavičić, Alfirević, \& Bežovan, 2017), differentiating trust in social institutions from trust in individual 
actors proved relevant for education and educational institutions. Loosely based on previous studies of stakeholder orientation within the population of Croatian principals and administrators of higher educational institutions (Alfirević, Pavičić, Mihanović, \& Relja, 2011; Pavičić, Alfirević, \& Mihanović, 2009), the present research used a modified classification of actors. Students, teachers, parents, and principals were classified as relevant individual actors/stakeholders, while the institutions considered included local and national educational administration, employers, educational associations, and, because of the Croatian context, institutions related to the educational reform (European Commission, 2017).

The relationship between educational management and leadership on the one hand, and school effectiveness on the other, has often been considered in scientific literature, usually as an outcome of adequate managerial and leadership practices (Gaziel, 1998; Hallinger \& Heck, 1998). As previously outlined, this study is an attempt to determine the existence of the public perception of an effective school as 'automatically' implying correct (i.e. professional) managerial practices. Regarding the measurement of school effectiveness and its multiple dimensions (Teddlie \& Reynolds, 2000), we have concentrated on goal attainment - the most fundamental and traditional effectiveness determinant - as a single measure (Brookover, Beady, Flood, Schweitzer, \& Wisenbaker, 1979; Edmonds, 1979). The effectiveness measurement can be improved by looking at schools as complex systems, which need to adapt to the environment, as well as achieve internal cohesion and staff commitment (Hoy \& Ferguson, 1985). Along the lines of systems theory, Miskel, Fevurly, \& Stewart (1979) used the dimensions of productivity, adaptability, and flexibility to measure school effectiveness, as perceived by teachers. Nevertheless, due to limited survey time and respondents' attention spans, it is difficult to expect the general public to be able to adequately measure school effectiveness by employing the complex systems theory. Therefore, we initially used two dimensions of goal attainment, traditionally found in literature on education in SEE (Giesecke \& Pavić, 1993; Jelavić, 1994). They are: knowledge/skills, as resulting from educational (academic) training, and other aspects of education such as values, personal and social growth and development, as conceptualized by the constructs of obrazovanje [education] and odgoj [upbringing] (original terms in Croatian), which are extremely difficult to translate into English concepts, used in international literature on education. Due to the popularity of the two constructs among the Croatian public, we used those two dimensions of goal attainment as measures of the public perception of school effectiveness. Since critical literature on education sees (and disapproves of) the acquisition of skills for the labour market as a single educational goal (Nóvoa, 2013), we included this dimension as a relevant measure of the public perception of school effectiveness.

We developed a simple questionnaire consisting of the following: three items measuring the perceived school effectiveness; three items related to the perception of the relative position of a national educational system within international educational benchmarking; and nine items that serve as a measure of public trust in institutions 
and actors relevant for the educational system. For all the described items we used the standard, symmetric, and equidistant Likert scale, with five levels of (dis)agreement with the item descriptions. The public perception of the typical role of school principals in the Croatian educational system has been assessed with a single item describing the position of an educational manager in terms of: (a) an independent managerial profession; (b) a political appointee; and (c) an honorary position. The nature of principal work has been developed by using an idealized dichotomy of political control vs. the decentralized decision-making of managerial professionals, as described by OECD (2016). A third dimension, based on qualitative research performed in Croatia (Vican, Sorić, \& Radeka, 2016), has been introduced.

\section{Research Hypotheses}

The working hypotheses for this study are as follows:

H1. Public interpretation of a country's relative position in international educational benchmarking studies influences the perception of school principalship as a managerial profession.

H2. Trust in relevant social institutions influences the perception of school principalship as a managerial profession.

H3. Trust in relevant individual social actors influences the perception of school principalship as a managerial profession.

H4. Perception of a country's overall school effectiveness drives the perception of school principalship as a managerial profession.

\section{Empirical Results}

Two previously described measures - trust in social institutions and individual actors relevant for education and educational institutions - were composed of five and four items (respectively). The preliminary check of internal validity has been performed by using the Cronbach alpha indicator with the respective values of 0.739 and 0.802 , which could be described as adequate in a relatively early stage of empirical research (Henson, 2001). The scale, which is related to educational effectiveness and consists of the three previously discussed items, had a similarly acceptable Cronbach alpha value of 0.735 . The descriptive statistics for independent variables are presented in Table 1.

A single scale has not been developed for the perception of the relative position within international educational benchmarking since it was conceptually difficult to assess the relative comparability of the items measured. In addition, there was no comparable previous empirical research, which is why we opted for an exploratory analysis of the three items included in the construct. We used the two-step cluster procedure, i.e. hierarchical clustering preceded by a pre-clustering algorithm. Firstly, we used the optimum number of clusters (as selected by the statistical analysis software), developed by applying the log-likelihood distance measure and the Schwarz-Bayesian Criterion. Seven clusters were created, which proved to be difficult for interpretation. 
Alfirević, Vican and Pavičić: What Drives the Perception of School Principals as Professional ...

Table 1

Descriptive statistics for independent variables

\begin{tabular}{lcccccc}
\hline Statistic & $\begin{array}{c}\text { Position of } \\
\text { educ. system } \\
\text { toward highly } \\
\text { developed EU } \\
\text { countries }\end{array}$ & $\begin{array}{c}\text { Position of } \\
\text { educ. system } \\
\text { toward other } \\
\text { EU countries }\end{array}$ & $\begin{array}{c}\text { Position of } \\
\text { educ. system } \\
\text { toward SEE } \\
\text { countries }\end{array}$ & $\begin{array}{c}\text { Trust in } \\
\text { institutions }\end{array}$ & $\begin{array}{c}\text { Trust in } \\
\text { individual } \\
\text { actors }\end{array}$ & $\begin{array}{c}\text { School } \\
\text { effectiveness } \\
\text { (overall) }\end{array}$ \\
\hline $\begin{array}{l}\text { Mean } \\
\text { Std. }\end{array}$ & 2.22 & 2.68 & 2.97 & 2.8414 & 3.3565 & 3.0735 \\
$\begin{array}{l}\text { Deviation } \\
\text { Minimum }\end{array}$ & 1.842 & 2.045 & 1.450 & .86007 & .93477 & .91779 \\
Maximum & 1 & 1 & 1 & .00 & .00 & .00 \\
\hline
\end{tabular}

With the fixed number of two clusters, the cluster quality drops from good to fair. The most important predictors are the position of the education system toward the highly developed EU countries (1.0), the other EU countries (0.30), and the SEE countries (0.11). The first cluster consists of $51.3 \%$ cases $(\mathrm{N}=303)$ and can easily be interpreted in terms of the position of the educational system which is equal to the most advanced EU countries, and better than the position of the educational system in both the other EU member states and the SEE countries. The second cluster consists of $48.7 \%(\mathrm{~N}=288)$ cases and can be interpreted in terms of the educational system position which is worse than in all the EU member states, but better than in the SEE countries. A cluster membership variable has been used in further analyses to describe those two configurations of the international educational benchmarks, as perceived by the Croatian public.

As many as $47.7 \%$ of the Croatian respondents believe that the position of a school principal is a political appointment, i.e. the direct transmission of educational policy onto the school level (see Table 2). This completely contradicts policy recommendations to develop principalship as an independent managerial profession (OECD, 2016). Only one third of the respondents perceive the school principal as an independent managerial professional, while $12.5 \%$ see principalship as an honorary position, e.g. relevant as an appointment for a senior teacher, before retirement.

Table 2

Descriptive statistics for the dependent variable

\begin{tabular}{lcccc}
\hline & Frequency & Percent & Valid Percent & Cumulative Percent \\
\hline Managerial profession & 196 & 33.1 & 33.1 & 33.1 \\
Honorary position & 74 & 12.5 & 12.5 & 45.7 \\
Political appointment & 282 & 47.7 & 47.7 & 93.3 \\
No answer & 39 & 6.7 & 6.7 & 100.0 \\
Total & 591 & 100.0 & 100.0 & \\
\hline
\end{tabular}

Since the focus of this study is to identify factors contributing to the perception of principals as independent managerial professionals, the dependent variable has 
been transformed into a dichotomous (true vs. false) variable, which can be applied to the analysis by using the binomial logistic regression. We acknowledge that such a procedure could introduce bias into the research results, which should be addressed in more elaborate statistical analyses in further research of this topic.

A bivariate correlations matrix for relevant variables (see Table 3) has been produced by using nonparametric (Spearman) indicators, due to the departure of their distributions from the assumption of normality (as checked by the KolmogorovSmirnov test). All the correlations are highly significant but of relatively low to moderate strength, which justified further analysis.

Table 3

Nonparametric bivariate correlations matrix

\begin{tabular}{lcccc}
\hline Spearman's rho statistic & $\begin{array}{c}\text { School } \\
\text { effectiveness } \\
\text { (overall) }\end{array}$ & $\begin{array}{c}\text { Trust in } \\
\text { institutions }\end{array}$ & $\begin{array}{c}\text { Trust in } \\
\text { individual } \\
\text { actors }\end{array}$ & $\begin{array}{c}\text { Principalship } \\
\text { perceived as a } \\
\text { profession }\end{array}$ \\
\hline School effectiveness (average) & 1.000 & $.421^{* *}$ & $.381^{* *}$ & $.237^{* *}$ \\
Trust in institutions & & 1.000 & $.585^{* *}$ & $.199^{* *}$ \\
$\begin{array}{l}\text { Trust in individual actors } \\
\text { Principalship perceived as a }\end{array}$ & & & 1.000 & $.345^{* *}$ \\
profession & & & & 1.000
\end{tabular}

${ }^{* *}$ Correlation is significant at the 0.01 level (2-tailed).

As previously discussed, the binomial logistic regression was conducted to identify the factors contributing to the perception of principalship as a profession among the Croatian public. The assumption of a linear relationship among the predictors to the log odds of the dependent variable has been checked by using the recommendations, provided by Box and Tidwell (1962). The Bonferroni correction was applied to the eleven terms, which resulted in the statistical significance of $\mathrm{p}<.0045$, used to accept the assumption of linearity. Three additional control variables were included into the model: gender, holding a higher education degree, and being a parent of (at least one) under-aged child (children) living in the same household. There were nine residuals with values higher than two standard deviations, which were excluded from the analysis.

The analysed model was significant, with $\chi^{2}(7)=97.41$, and the difference between the baseline (constant-only) and the research model highly significant $(\mathrm{p}<0.001)$. The percentage of correctly classified cases is $70.4 \%$, with the model explaining $21.4 \%$ of the variance in principalship perception (according to the Nagelkerke $\mathrm{R}^{2}$ indicator). The statistical significance of the predictors is presented in Table 4 .

Trust in institutions relevant for education has not proven to be a significant predictor of principalship as a managerial profession, which is in line with the research propositions made by Pavičić, Alfirević, and Bežovan (2017), as well as sociological studies, demonstrating low trust in institutions, being replaced by informal and family ties in the SEE region (Pichler \& Wallace, 2007). Trust in relevant individual actors 
who might be able to influence the educational system, and its development by 'heroic' acts and transformational capabilities has proven to be a significant predictor of the perception of principalship as a profession $(\mathrm{p}<0.01)$. Reliance on individual social actors, rather than established institutions, could be attributed to the specific social characteristics of the SEE region. This can be compared to the results of existing research on collective actions in local communities (Pavičić, Alfirević, \& Bežovan, 2017). The size of the effect is fairly impressive, since the increase of one relative unit of public trust in individual social actors relevant for education (as measured on the five-level scale), increases the odds of perceiving principalship as an independent managerial profession by as much as 3.12 times.

Table 4

Binomial logistic regression, predicting probability of perceiving principalship as a profession

\begin{tabular}{|c|c|c|c|c|c|c|}
\hline \multirow[t]{2}{*}{ PREDICTORS } & \multirow[t]{2}{*}{$\begin{array}{l}\text { Constant } \\
\text { (Intercept) }\end{array}$} & \multirow[t]{2}{*}{$\begin{array}{l}\text { Standard } \\
\text { error }\end{array}$} & \multirow[t]{2}{*}{ Sig. } & \multirow[t]{2}{*}{$\operatorname{Exp}(B)^{*}$} & \multicolumn{2}{|c|}{$\begin{array}{l}95 \% \text { confidence } \\
\text { interval for the odds } \\
\text { ratio }\end{array}$} \\
\hline & & & & & Lower & Upper \\
\hline Trust in institutions & -.165 & .165 & .318 & .848 & .614 & 1.172 \\
\hline Trust in individual actors & 1.139 & .192 & .000 & 3.123 & 2.145 & 4.547 \\
\hline $\begin{array}{l}\text { School effectiveness } \\
\text { (average) }\end{array}$ & .531 & .143 & .000 & 1.701 & 1.285 & 2.252 \\
\hline $\begin{array}{l}\text { Configuration of } \\
\text { international educational } \\
\text { benchmark clusters }\end{array}$ & -.119 & .208 & .568 & .888 & .590 & 1.336 \\
\hline Gender & .023 & .196 & .906 & 1.023 & .697 & 1.502 \\
\hline $\begin{array}{l}\text { Holding a higher education } \\
\text { degree }\end{array}$ & -.197 & .262 & .453 & .821 & .491 & 1.373 \\
\hline $\begin{array}{l}\text { Parent of (at least one) } \\
\text { under-aged child (children) } \\
\text { living in the same household }\end{array}$ & -.011 & .198 & .956 & .989 & .671 & 1.458 \\
\hline Constant & -5.751 & .727 & .000 & .003 & & \\
\hline
\end{tabular}

*Exponentiation of the B coefficient (odds ratio)

The same conclusion applies to the perception of school effectiveness, which shows that not only do the 'correct' practices of educational leadership and management lead to enhanced effectiveness, but that the relationship seems to work the other way as well. Namely, there is a significant effect of the perceived overall school effectiveness as a predictor of managerial professionalization. With each unit of the increase of the public perception of school effectiveness (as measured on the five-level scale), the odds for principalship to be perceived as an independent managerial profession become 1.70 times higher. Therefore, effective schools are perceived as being led by principals, publicly recognized as managers.

It is interesting that perceptions of international education benchmarks did not prove to be a relevant predictor. This could be explained by a previous study which 
shows that the public perception of such international studies might not be completely correct, at least in the case of Croatia (Vican, Alfirević, \& Pavičić, 2017). It is also interesting that none of the included control variables proved to be a significant predictor of the perception of principalship as a managerial career, indicating that the demographic variables might not contribute significantly to the perception of the principals' profession.

\section{Conclusion and Policy Implications}

Out of the four proposed hypotheses, only trust in individual actors (hypothesis H2) and the perception of a given country's school effectiveness (hypothesis $\mathrm{H} 4$ ) proved to be significant predictors of the public perception of the principalship profession in Croatia. The other two hypothesized predictors - trust in social institutions and a country's relative position in international educational benchmarking studies (hypotheses $\mathrm{H} 1$ and $\mathrm{H} 3$ ) - were not found to be empirically significant.

The dichotomy of trust in institutions and the social structure versus individual actors to whom stakeholders have personal, family-based, or social connections, is a well-researched sociological topic in the SEE region. Its generic findings which determine the formation of social capital, the functioning of civil society, and community/social actions, seem to be applicable to the field of educational policy as well. The obtained results may be empirically relevant for educational research and interesting for management researchers looking into the application of their theories to educational management and leadership field(s), but it is hardly an exciting topic to report on.

The other predictor, found to be empirically relevant on a nationally representative sample of Croatian households, tells a different story. It is linked to the social construction of the managerial profession and the effectiveness concepts, which have already been discussed in a somewhat related field of non-profit management. The easily comprehensible link between professional school management/principalship and higher educational performance (effectiveness) can easily be reversed as well.

Namely, due to relatively large gaps between public opinion and the results of international benchmarking studies (as suggested by Vican, Alfirević, \& Pavičić, 2017), believed to be an objective indicator of educational performance, school effectiveness could prove to be socially constructed. The obtained empirical results of this study, which rejects the empirical significance of international benchmarking as a factor of the public perception of principal professionalization, seem to confirm such findings.

In our sample, the social perception of educational institutions (or practices) as highly effective leads to the recognition/construction of principalship, viewed in terms of a managerial profession. The public perception, thus, works both ways: the perception of 'right' practices leads to the perception of effectiveness and vice versa. Future research should demonstrate whether there are some additional constructs that moderate or mediate the relationship, as well as whether the size of the effect varies over time. 
There are interesting public policy implications arising from the obtained results. Social trust and its influence on public policies based on networks of personal ties and opinions, rather than objective, evidence-based processes, seems to be confirmed once again in the case of South-East Europe (SEE). Even more interesting is the emerging pattern of public perception and policy-making, which could be applied by SEE policy actors and stakeholders. It is related to the construction of positive narratives and evidences of 'good practices' found on individual and institutional levels, to be directed toward relevant policy publics. Such a recommendation should not be interpreted in terms of supporting the contested practice, which reduces public policy-making into a form of a low-level public relation 'stunt', as employed by some low-capacity public servants and even certain levels of governments in the region. Rather, it is directed toward strengthening the local and/or regional capacity to act and make political choices, leading to positive policy outcomes. This entails the need for political elites and policy actors in small countries to take real responsibility for their actions, which can easily be avoided with the empty rhetoric of 'depoliticizing' the policy process. Experts and expert committees can be useful in both policymaking and benchmarking, as well as the implementation of EU recommendations, but they cannot replace policy makers' vision and commitment. Ultimately, the policy publics' hearts and minds cannot be won with 'technocratic' narratives, but rather with evidence of local and regional 'good practices', which are officially sanctioned and institutionalized on the systemic level. This should be intertwined with institutional capacity building and an attempt to create a positive feedback loop, emphasizing mutual links between the development of local resources and communication of positive local narratives.

In addition, given that public relations practices in Croatia are highly personalized and influenced by individual relationships (Taylor, 2004), the construction of negatively pitched narratives and media influences proves to be a realistic option for some policy actors seeking public influence. Our recommendation also seems to be a good approach to countering such attempts of 'rogue' policy-making. We also hope that our results can be generalized via future research on small countries in the SEE region and beyond, which could provide realistic options to political elites and incumbent policy-makers for creating and sustaining successful educational policies.

\section{Acknowledgement}

Empirical research for this paper has been financially supported by the Ministry of Science and Education of the Republic of Croatia, within the activities of the Scientific Centre of Excellence for School Effectiveness and Management. 


\section{References}

Alfirević, N., Burušić, J., Pavičić, J., \& Relja, R. (Eds.) (2016). School Effectiveness and Educational Management: Towards a South-Eastern Europe Research and Public Policy Agenda. London: Palgrave Macmillan. https://doi.org/10.1007/978-3-319-29880-1

Alfirević, N., Pavičić, J., Mihanović, Z., \& Relja, R. (2011). Stakeholder-oriented principal development in Croatian elementary schools. Revija za socijalnu politiku, 18(1), 47-60. https://doi.org/10.3935/rsp.v1i1.962

Alfirević, N., Pavičić, J., \& Relja, R. (2016). School management innovation and principal support systems: Toward the agenda for Croatian school reform. Ekonomska istraživanja, 29, 1150-1164. https://doi.org/10.1080/1331677X.2016.1213650

Box, G. E. P., \& Tidwell, P. W. (1962). Transformation of the independent variables. Technometrics, 4, 531-550. https://doi.org/10.1080/00401706.1962.10490038

Breakspear, S. (2012). The Policy Impact of PISA: An Exploration of the Normative Effects of International Benchmarking in School System Performance. https://doi. org/10.1787/5k9fdfaffr28-en

Brookover, W. B., Beady, C., Flood, P., Schweitzer, J., \& Wisenbaker, J. (1979). School social systems and student achievement: Schools can make a difference. New York: Praeger Publishers.

Burstein, P. (1998). Bringing the public back in: Should sociologists consider the impact of public opinion on public policy? Social Forces, 77, 27-62. https://doi.org/10.1093/ $\underline{\text { sf/77.1.27 }}$

Burstein, P. (2003). The impact of public opinion on public policy: A review and an agenda. Political Research Quarterly, 56, 29-40. https://doi.org/10.1177/106591290305600103

Cho, Y. H. \& Palmer, J. D. (2013). Stakeholders'views of South Korea's higher education internationalization policy. Higher Education, 65, 291-308. https://doi.org/10.1007/s10734012-9544-1

Cook, F. L., Tyler, T. R., Goetz, E. G., Gordon, M. T., Protess, D., Leff, D. R., \& Molotch, H. L. (1983). Media and agenda setting: Effects on the public, interest group leaders, policy makers, and policy. Public Opinion Quarterly, 47, 16-35. https://doi.org/10.1086/268764

Creemers, B. (2006). The importance and perspectives of international studies in educational effectiveness. Educational Research and Evaluation, 12, 499-511. https://doi. org/10.1080/13803610600873978

Edmonds, R. (1979). Effective schools for the urban poor. Educational Leadership, 37, 15-24.

European Commission (2017). Education and Training Monitor 2017: Croatia. Retrieved from https://ec.europa.eu/education/sites/education/files/monitor2017-hr en.pdf.

Gaziel, H. (1998). School-based management as a factor in school effectiveness. International Review of Education, 44, 319-333. https://doi.org/10.1023/A:1003265723206

Giesecke, H., \& Pavić, Ž. (1993). Uvod u pedagogiju. Zagreb: Educa.

Glatter, R., \& Lesley, K. (2003). 'Best Practice’ in Educational Leadership and Management: Can We Identify It and Learn from It? Educational Management and Administration, 31, 231-243. https://doi.org/10.1177/0263211X03031003002 
Alfirević, Vican and Pavičic: What Drives the Perception of School Principals as Professional ...

Granovetter, M. (1985). Economic action and social structure: The problem of embeddedness. American Journal of Sociology, 91, 481-510. https://doi.org/10.1086/228311

Grek, S. (2009). Governing by numbers: The PISA 'effect' in Europe. Journal of Education Policy, 24, 23-37. https://doi.org/10.1080/02680930802412669

Grunig, J. E., \& Hunt, T. (1984). Managing Public Relations. New York: Holt, Rinehart and Winston.

Hallinger, P., \& Heck, R. H. (1998). Exploring the principal's contribution to school effectiveness: 1980-1995. School Effectiveness and School Improvement, 9, 157-191. https:// doi.org/10.1080/0924345980090203

Hanushek, E. A., \& Woessmann, L. (2010). The High Cost of Low Educational Performance: The Long-Run Economic Impact of Improving PISA Outcomes. Paris: OECD Publishing.

Heck, R. H., \& Hallinger, P. (2005). The study of educational leadership and management: Where does the field stand today? Educational Management Administration and Leadership, 33, 229-244. https://doi.org/10.1177/1741143205051055

Herman, R. D., \& Renz, D. O. (1997). Multiple Constituencies and the Social Construction of Non-profit Organization Effectiveness. Non-profit and Voluntary Sector Quarterly, 26, 185-206. https://doi.org/10.1177/0899764097262006

Herman, R. D., \& Renz, D. O. (1998). Non-profit Organizational Effectiveness: Contrasts Between Especially Effective and Less Effective Organizations. Non-profit Management and Leadership, 9, 23-38. https://doi.org/10.1002/nml.9102

Herman, R. D., \& Renz, D. O. (2008). Advancing Non-profit Organizational Effectiveness Research and Theory: Nine Theses. Non-profit Management and Leadership, 18, 399-415. https://doi.org/10.1002/nml.195

Hoy, W. K., \& Ferguson, J. (1985). A theoretical framework and exploration of organizational effectiveness of schools. Educational Administration Quarterly, 21, 117-134. https://doi. org/10.1177/0013161X85021002006

Jelavić, F. (1994). Didaktičke osnove nastave. Zagreb: Naklada Slap.

Jongbloed, B., Enders, J., \& Salerno, C. (2008). Higher education and its communities: Interconnections, interdependencies and a research agenda. Higher Education, 56, 303 324. https://doi.org/10.1007/s10734-008-9128-2

Little, J. W. (1993). Teachers' professional development in a climate of educational reform. Educational Evaluation and Policy Analysis, 15, 129-151.

Miskel, C. G., Fevurly, R., \& Stewart, J. (1979). Organizational structures and processes, perceived school effectiveness, loyalty, and job satisfaction. Educational Administration Quarterly, 15(3), 97-118. https://doi.org/10.1177/0013131X7901500308

Nóvoa, A. (2013). The blindness of Europe: New fabrications in the European educational space. Sisyphus Journal of Education, 1, 104-123.

OECD (2016). PISA 2015 Results (Volume II): Policies and Practices for Successful Schools. Paris: OECD Publishing.

Padanyi, P., \& Gainer, B. (2004). Market Orientation in the Non-profit Sector: Taking Multiple Constituencies into Consideration. Journal of Marketing Theory and Practice, 12(2), 43-58. https://doi.org/10.1080/10696679.2004.11658518 
Page, B. I., \& Shapiro, R. Y. (1983). Effects of public opinion on policy. American Political Science Review, 77, 175-190. https://doi.org/10.2307/1956018

Pavičić, J., Alfirević, N., \& Mihanović, Z. (2009). Market orientation in managing relationships with multiple constituencies of Croatian higher education. Higher Education, 57, 191-207. https://doi.org/10.1007/s10734-008-9141-5

Pavičić, J., Alfirević, N., \& Bežovan, G. (2017). Community capacity, sense of community and social capital: The sociological and economic dimensions in Croatia and Serbia. Annales - Anali za istrske in mediteranske študije - Series Historia et Sociologia, 27, 553-562.

Pichler, F., \& Wallace, C. (2007). Patterns of formal and informal social capital in Europe. European Sociological Review, 23, 423-435. https://doi.org/10.1093/esr/jcm013

Pont, B., Nusche, D., \& Moorman, H. (2008). Improving School Leadership, Volume 1: Policy and Practice. Paris: OECD Publishing.

Radaelli, C. M. (2003). The Europeanization of public policy. In K. Featherstone, \& C. M. Radaelli (Eds.), The Politics of Europeanization (pp. 27-56). Oxford: Oxford University Press. https://doi.org/10.1093/0199252092.003.0002

Rothstein, B., \& Stolle, D. (2008). The state and social capital: An institutional theory of generalized trust. Comparative Politics, 40, 441-459. https://doi.org/10.5129/00104150 $\underline{8 X 12911362383354}$

Sentočnik, S., \& Rupar, B. (2009). School leadership of the future: How the national education institute in Slovenia supported schools to develop distributed leadership practice. European Education, 41(3), 7-22. https://doi.org/10.2753/EUE1056-4934410301

Taylor, M. (2004). Exploring public relations in Croatia through relational communication and media richness theories. Public Relations Review, 30, 145-160. https://doi.org/10.1016/j. pubrev.2003.09.003

Teddlie, C., \& Reynolds, D. (Eds.) (2000). The International Handbook of School Effectiveness Research. London/New York: Falmer Press (Taylor \& Francis).

Vican, D., Sorić, I., \& Radeka I. (Eds.) (2016). Upravljanje odgojno-obrazovnom ustanovom: kompetencijski profil ravnatelja. Zadar: University of Zadar.

Vican, D., Alfirević, N., \& Relja, R. (2016). Managing the School: Principals as Managers. In N. Alfirević, J. Burušić, J. Pavičić, \& R. Relja (Eds.), School Effectiveness and Educational Management (pp. 67-85). London: Palgrave Macmillan. https://doi.org/10.1007/978-3$\underline{319-29880-1 \quad 5}$

Vican, D., Alfirević, N., \& Pavičić, J. (2017). Challenges facing the educational system, school effectiveness \& principals in Croatia. In D. Križman Pavlović, M. Paulišić, \& K. Kostelić (Eds.), Socioeconomic Challenges of the Future World (pp. 11-29). Pula: Juraj Dobrila University of Pula, Faculty of Economics and Tourism Dr. Mijo Mirković.

Warner, M. (2002). Publics and counterpublics. Public Culture, 14, 49-90. https://doi. org/10.1215/08992363-14-1-49 


\section{Nikša Alfirević}

University of Split, Faculty of Economics, Business and Tourism Cvite Fiskovića 5, 21000 Split, Croatia

nalf@efst.hr

\section{Dijana Vican}

University of Zadar, Department of Pedagogy

Mihovila Pavlinovića 1, 23000 Zadar, Croatia

dvican@unizd.hr

\section{Jurica Pavičić}

University of Zagreb, Faculty of Economics and Business Trg J F Kennedy 6, 10000 Zagreb, Croatia

jpavicic@efzg.hr 


\section{Što oblikuje percepciju školskih ravnatelja kao profesionalnih menadžera u malim europskim državama? Slučaj Hrvatske}

\section{Sažetak}

U ovom se radu istražuju obrazovni i društveni faktori koji pridonose percepciji školskih ravnatelja kao neovisne menadžerske profesije. Empirijski su rezultati dobiveni ispitivanjem kućanstava reprezentativnih za Republiku Hrvatsku, malu europsku država koja provodi opsežnu reformu obrazovanja. Empirijski rezultati sugeriraju da povjerenje u pojedine društvene aktere koji su relevantni za obrazovanje i javna percepcija učinkovitosti škola mogu služiti kao čimbenici prognoze javne procjene ravnateljske profesije. Iznose se moguće implikacije za buduća istraživanja i razvoj politika u malim europskim državama. Predložene intervencije u politiku naglašavaju sposobnost institucionalne izgradnje, kao i pokušaj kreiranja pozitivnih povratnih informacija jačanjem međusobnih poveznica izmedu razvoja lokalnih resursa i dijeljenja pozitivnih lokalnih narativa.

Ključni pojmovi: Hrvatska; obrazovni menadžment; prediktorske varijable; profesija; školski ravnatelji.

\section{Uvod}

Istraživačko pitanje predstavljeno u ovome radu odnosi se na identifikaciju i empirijsko ispitivanje čimbenika koji oblikuju javnu percepciju školskih ravnatelja kao menadžerske profesije u Hrvatskoj. Budući da razvoj profesionaliziranog i raspodijeljenog rukovodstva na području obrazovanja pridonosi učinkovitosti obrazovnih sustava u cjelini (OECD, 2016), uključivanje relevantnih javnosti (zainteresiranih dionika) u taj proces moglo bi biti od velike važnosti za obrazovanje u Hrvatskoj.

Profesionalizacija školskih ravnatelja od velike je važnosti za uspjeh nacionalnih obrazovnih sustava (Pont, Nusche, i Moorman, 2008), što, pak, pridonosi ostvarivanju opipljivih rezultata na području ekonomskog razvoja i kompetitivnosti nacionalnih ekonomija (Hanushek i Woessmann, 2010). Nužnost decentralizacije školske uprave i njezina odvajanja od političkih i administrativnih struktura još uvijek nije prepoznata 
unutar hrvatske obrazovne politike. Usprkos različitim inicijativama koje su razvijane tijekom više od dvadeset godina, prepoznavanje školskih ravnatelja kao neovisne menadžerske profesije na nacionalnoj razini više je puta odgađano. Godina 2021. definirana je kao najnoviji rok za profesionalizaciju zanimanja ravnatelja. Nadalje, lokalna je baza znanja o obrazovnom menadžmentu i teoriji rukovođenja ograničena (Vican, Alfirević, Relja, 2016).

Zabilježene su uspješne temeljne aktivnosti koje pridonose razvoju školske uprave i rukovodstva u Hrvatskoj. U razdoblju od 2015. do 2017. godine javno hrvatsko sveučilište srednje veličine uspjelo je privući znatnu potporu fondova Europske unije i razviti profesionalne standarde za obrazovne menadžere/vođe, te osnovati jednogodišnji poslijediplomski program za rukovodstvo u obrazovanju. Istraživači na području obrazovanja i akteri politika u regiji jugoistočne Europe (JIE) mogli bi biti zainteresirani za takve primjere dobre obrazovne prakse, iako bi prednost trebao imati sustavan pristup razvoju rukovodstva na području obrazovanja. Jedan takav sustav trenutno je na snazi u Sloveniji, gdje su profesionalni standardi za zanimanje ravnatelja uvedeni, a formalne kvalifikacije rukovodstva razvijene još 1995 . godine (Sentočnik i Rupar, 2009).

Budući da su druge zemlje JIE ostvarile još manje u vezi s razvojem profesionalnih obrazovnih menadžera i profesionalnih standarda toga zanimanja, rezultati ovdje predstavljenog istraživanja mogli bi biti važni na regionalnoj razini i informativni za obrazovnu politiku drugih malih europskih zemalja, naročito onih zemalja koje nastoje provesti obrazovne reforme u skladu s preporukama transnacionalnih organizacija. Te preporuke uključuju decentralizaciju obrazovne uprave i profesionalizaciju školskih ravnatelja (vidi, npr. OECD, 2016; Pont, Nusche, Moorman, 2008).

Nadalje, Burstein (1998) poziva sociologe da ispitaju javno mišljenje i njegovu vezu s javnim politikama, što još nije obrađeno u stručnoj literaturi (barem kad je riječ o malim europskim zemljama). Postojeća literatura koja propitkuje spomenutu vezu ukazuje na snažan utjecaj javnog mišljenja, naročito kad je riječ o relevantnim pitanjima (Burstein, 2003; Page i Shapiro, 1983). U slučaju Hrvatske, čini se da društveni znanstvenici zanemaruju odnos između javnog mišljenja, utjecaja medija i javnih politika. Za njih, čini se, taj je odnos više stvar 'praktičnih politika' nego znanstvenog diskursa, iako Cook, Tyler, Goetz, Gordon, Protess, Leff i Molotch (1983) ističu važnost medijske prakse razvijanja programa za javno mišljenje i kreiranje politika. Istodobno, svi aspekti obrazovne reforme za hrvatsku su javnost osobito važno pitanje kojemu je posvećeno mnogo medijske pozornosti.

\section{Pregled postojećih istraživanja}

Razvoj obrazovnih profesionalaca u kontekstu obrazovne reforme nije nova tema istraživanja. Devedesetih godina prošloga stoljeća modele profesionalnog razvoja učitelja smatralo se komponentom cjelokupne inicijative za reformu. U skladu s preporukama, tradicionalno osposobljavanje učitelja iznova se razmatralo u skladu 
sa širim nacrtom reforme (Little, 1993). Alfirević, Pavičić, Relja (2016) sličan pristup primjenjuju u istraživanju profesionalizacije ravnatelja: autori promoviraju uporabu određenih alata za trening i podršku, koje se, pak, mijenja i prilagođava u skladu sa zahtjevima suvremene pedagogije i plana nacionalne reforme obrazovanja. Ta je vrsta usklađivanja važna jer, kako upozoravaju Heck i Hallinger (2005), istraživači, praktičari i akteri politika na području obrazovanja zajedničke interese i ciljeve percipiraju i kontekstualiziraju na različitih načine. Pritom među njima nerijetko izostaje razumijevanje.

Tema ovog rada - javno mišljenje o zanimanju školskog ravnatelja - može se konceptualizirati putem stavova zainteresiranih dionika. Te se dionike, pak, također može konceptualizirati putem pojma javnosti (Warner, 2002). Koncept javnosti jedan je od ključnih pojmova teorije i prakse javnih odnosa (Gruning i Hunt, 1984), no do sada se rijetko koristio u obrazovnoj praksi, odnosno primjenjivao na obrazovne konstrukte/procese. S druge strane, logika upravljanja višestrukim javnostima i njihovim očekivanjima postala je važan dio istraživanja obrazovanja, naročito u analizi zainteresiranih dionika i upravljanja odnosa među zainteresiranim dionicima, osobito na polju višeg obrazovanja (vidi, npr. Cho i Palmer, 2013; Jongbloed, Enders i Salerno, 2008; itd.).

Namjera nam je primijeniti logiku istraživanja javnih odnosa i upravljanja zainteresiranim dionicima na menadžment i rukovodstvo obrazovanja, kao jednog od glavnih područja obrazovne politike. Vjerujemo da je moguće formulirati i primijeniti uravnotežene politike tako da se razumiju i obrade očekivanja zainteresiranih dionika (javnosti), empirijski prikazana u slučaju višeg obrazovanja u Hrvatskoj (Pavičić, Alfirević i Mihanović, 2009).

Optimalne politike trebalo bi ostvariti uravnoteživanjem očekivanja relevantnih zainteresiranih dionika (tj. javnosti), putem analogije $s$ istraživanjem djelovanja neprofitnih organizacija. Naime, kompleksnost i raznolikost koje karakteriziraju područje javne politike, kao i krajobraz neprofitnih organizacija, zahtijevaju urođenu usmjerenost na višestruke zainteresirane dionike/izborne jedinice/javnosti (Padanyi i Gainer, 2004). Dok 'žongliraju' višestrukim društvenim poticajima i zahtjevima, menadžeri neprofitnih organizacija moraju ostvariti društveno konstruiran konsenzus između osobne i organizacijske učinkovitosti (Herman i Renz, 1997). Čak i kada se društveni konstruktivizam prepoznaje priznavanjem djelovanja, često postoji širi konsenzus između tehnika i menadžerskih pristupa, koji širok raspon javnosti smatra suvremenim i relevantnim za cjelokupan društveni kontekst. Smatra se da njihova uporaba omogućava razlikovanje učinkovitijih od manje učinkovitih organizacija (Herman i Renz, 1998) te definiraju središnje percepcije onoga što predstavlja organizacijsku učinkovitost u teoriji i menadžerskoj praksi (Herman i Renz, 2008).

Slično tome, o pitanjima politike valja odlučiti uzimanjem u obzir najznačajnijih faktora prognoze percepcije i očekivanja javnosti. Na taj se način rješava problem ograničenja inherentnih ideji neograničene primjene benchmarkinga. Benchmarking 
se odnosi na proces identifikacije i primjene najboljih svjetskih praksi, uz veće ili manje preinake i modifikacije nacionalnih obrazovnih sustava i njihovih društvenih konteksta. Kao što sugeriraju Glatter i Kydd (2003), 'najbolje' prakse identificirane u kontekstima različitih društvenih (i drugih) karakteristika nije moguće svugdje 'automatski' primijeniti, naročito ako se zanemaruju očekivanja lokalnih javnosti vezana uz politike.

Iz spomenutih razloga zagovaramo kontekstualizirani pristup identifikaciji 'dobrih' obrazovnih praksi (nasuprot 'najboljim' praksama) i njihovoj primjeni. U tom procesu valja iskoristiti postojeće faktore koji oblikuju percepciju javnosti i težiti uravnoteženom pristupu društveno konstruiranom konsenzusu onoga što predstavlja 'cjelokupni interes' obrazovnog sustava zemlje u razvoju. Analogijom s preporukama proizašlim iz istraživanja djelovanja neprofitnih organizacija učinkoviti donositelji javnih politika (uključivši i one koje na politike samo utječu) trebaju biti oprezni kad je riječ o takvim - da se poslužimo sociološkim pojmom koji uvodi Granovetter (1995) - pokretačima uspjeha politika uklopljenim u društvo.

Uzmemo li u obzir cjelokupno područje javne politike, naš bi se pristup mogao primijeniti i na paradoks nominalnog prihvaćanja 'europeizacije' političkog procesa sa svrhom dobivanja statusa države članice Europske unije i/ili financijske pomoći iz europskih fondova. Čitav 'europeizacijski' pristup javnoj politici (Radaelli, 2003), kako ga primjenjuju zemlje koje apliciraju za članstvo (ili su nedavno postale članice) Europske unije, dao bi se bolje razumjeti i kontekstualizirati razmatranjem političkih ograničenja koje nameću lokalne/regionalne javnosti. Svakako se radi o otvorenijoj i poštenijoj alternativi razmatranju tih zemalja u kontekstu njihove (veće ili manje) zrelosti i sposobnosti prilagođavanja 'najboljim' (europskim ili drugim transnacionalnim) praksama/referentnim točkama.

\section{Metodologija}

\section{Populacija i uzorak}

Ovo istraživanje obuhvaća populaciju Republike Hrvatske, a osmišljeno je tako da spomenuti uzorak predstavlja na razini kućanstva. Koristeći se javno dostupnim telefonskim imenicima postojećih telekomunikacijskih operatera kao okvirom za skupljanje uzorka kreirali smo ponderirani, nacionalno reprezentativan uzorak hrvatskih kućanstava. Uz pomoć programskog paketa Computer-Aided Telephone Interviewing (skrać. CATI, računalno potpomognuti telefonski intervjui) koji podržava vjerojatnosno prikupljanje uzoraka, nasumce je odabrano 591 kućanstvo. Kako bi se postigla nacionalna reprezentativnost na razini kućanstva, uzorak je ponderiran prema kriterijima dobi, roda, obrazovanja i geografske lokacije. Koeficijenti su dobiveni na temelju rezultata prethodnog popisa stanovništva Republike Hrvatske. Za unos, kodiranje i analizu rezultata koristio se softverski paket za statističku obradu podataka SPSS. Očito ograničenje korištenja pristupa usmjerenog na javno mišljenje za prikupljanje uzorka odnosi se na prirodu rezultata istraživanja, koji odražavaju 
javnu percepciju mjerenih konstrukata. Bez obzira na to ovaj tip pristupa mogao bi se pokazati korisnim za političke aktere u malim europskim zemljama, koji bi željeli procijeniti važnost dionika u obrazovnim politikama i utjecaj njihove percepcije na politički proces.

\section{Konstrukti, mjere i instrument istraživanja}

Uzimajući u obzir brojne postojeće studije na području benchmarkinga međunarodnog obrazovanja, naročito PISA istraživanja (pod pokroviteljstvom Organizacije za ekonomsku suradnju i razvoj, skrać. OECD) i njihov utjecaj na obrazovnu politiku (Breakspear, 2012; Creemers, 2006; Grek, 2009), relativni položaj pojedine države unutar istraživanja benchmarkinga međunarodnog obrazovanja, kao i interpretacija tih istraživanja od šire javnosti smatraju se relativnim čimbenicima prognoze profesionalizacije ravnatelja.

Iz sociološke perspektive važnim bi se mogao pokazati i društveni kapital. O mjerenju društvenog kapitala razinom javnog povjerenja $u$ institucije i pojedinačne aktere važne u obrazovnom kontekstu bit će više riječi o ovom dijelu rada.

Budući da se konstrukt učinkovitosti škola više puta dovodio u vezu s menadžmentom i rukovođenjem škola (Hallinger i Heck, 1998), posljednji potencijalni čimbenik vezan je uz javnu percepciju učinkovitosti škola. Bez obzira na to zanima nas obrtanje tradicionalnih pretpostavki kako bismo ustanovili postoji li javno priznavanje (konsenzus) u vezi sa školskom učinkovitošću, uzrokovano dobro prihvaćenim menadžerskim i rukovoditeljskim praksama, s posebnim fokusom na profesionalizaciji i menadžerskom statusu ravnatelja.

Koristile su se i tri kontrolne varijable koje uključuju rod ispitanika, razinu njihova obrazovanja (s posebnim naglaskom na stupnju formalnog višeg obrazovanja), kao i status roditelja malodobnog djeteta koje živi u istom kućanstvu.

Percepcija relativnog položaja unutar benchmarkinga međunarodnog obrazovanja pokazala se kao konstrukt koji je naročito teško izmjeriti. Izbjegavali smo mjere utemeljene na poredcima stvarnog benchmarkinga. Tu odluku podržavaju i rezultati naših prijašnjih istraživanja (Vican, Alfirević i Pavičić, 2017), koji upućuju na postojanje znatnog jaza u istraživanju PISA testova, proizašlog iz usporedbe stvarnih rezultata obrazovnog benchmarkinga i njihove javne percepcije u Hrvatskoj. Kako bi istraživanje učinili što pristupačnijim ispitanicima, uveli smo tri naknadne usporedbe hrvatskog obrazovnog sustava s onim najrazvijenijih država članica Europske unije, ostalih država članica Europske unije, kao i malih država u jugoistočnoj Europi (JIE). Kategorije se temelje na pregledu teorije o menadžmentu i rukovođenju obrazovanja, te onim njihovim obilježjima koja su specifična za regiju jugoistočne Europe (Alfirević, Burušić, Pavičić, Relja, 2016).

Povjerenje javnosti u političke i pravne institucije naglašava se kao glavni izvor društvenog kapitala (Rothstein i Stolle, 2008). Bez obzira na to, mjerenje povjerenja u institucije koje je lako prepoznati na razini zajednice također je složena zadaća. 
Na temelju nedavno objavljene studije o razlikama u percepciji društvenog kapitala u Hrvatskoj i Srbiji na razini lokalnih zajednica (Pavičić, Alfirević i Bežovan, 2017), razlikovanje povjerenja u društvene institucije od povjerenja u pojedine aktere pokazalo se relevantnim za obrazovanje i obrazovne institucije. Djelomice utemeljeno na postojećim studijama orijentacija zainteresiranih dionika unutar populacije hrvatskih ravnatelja i administratora institucija višeg obrazovanja (Alfirević, Pavičić, Mihanović, Relja, 2011; Pavičić, Alfirević, i Mihanović, 2009), ovdje predstavljeno istraživanje koristi se modificiranom klasifikacijom aktera. Učenici, učitelji, roditelji i ravnatelji klasificirani su kao relevantni pojedinačni akteri/zainteresirani dionici, a da institucije obuhvaćene istraživanjem uključuju lokalne i nacionalne obrazovne administracije, poslodavce, obrazovne udruge te, s obzirom na hrvatski kontekst, institucije vezane uz reformu obrazovanja (European Commission, 2017).

Odnos između obrazovnog menadžmenta i vođenja s jedne, te učinkovitosti škola s druge strane, česta je tema u znanstvenoj literaturi, koja spomenuti odnos često opisuje kao posljedicu odgovarajućih menadžerskih i rukovoditeljskih praksi (Gaziel, 1998; Hallinger i Heck, 1998). Kao što je prije naznačeno, ovo je istraživanje pokušaj utvrđivanja postojanja javne percepcije učinkovite škole kao institucije koja 'automatski' upućuje na postojanje ispravnih (tj. profesionalnih) menadžerskih praksi. Kad je riječ o mjerenju učinkovitosti škole i njezinih višestrukih dimenzija (Teddlie i Reynolds, 2000), usredotočili smo se na ostvarivanje ciljeva (u kojem prepoznajemo najtemeljnije i najtradicionalnije sredstvo utvrđivanja učinkovitosti) kao jedinstvenu mjeru (Brookover, Beady, Flood, Schweitzer, i Wisenbaker, 1979; Edmonds, 1979). Mjeru učinkovitosti moguće je unaprijediti sagledavanjem škola kao složenih sustava koji se trebaju prilagoditi okolini te ostvariti unutarnju koheziju i predanost osoblja (Hoy i Ferguson, 1985). Oslanjajući se na teoriju sustava, Miskel, Fevurly i Stewart (1979) koriste se dimenzijama produktivnosti, prilagodljivosti i fleksibilnosti kao mjere školske učinkovitosti, kako je vide učitelji. Međutim, s obzirom na ograničeno vrijeme isipitivanja i pozornost ispitanika teško je očekivati da će šira javnost moći na odgovarajući način mjeriti učinkovitost škola koristeći se teorijom složenih sustava. Zbog toga smo se inicijalno koristili sljedećim dvjema dimenzijama ostvarivanja ciljeva koje se tradicionalno javljaju u literaturi o obrazovanju u JIE (Giesecke i Pavić, 1993; Jelavić, 1994): znanja/vještine koja/e proizlaze iz obrazovnog (akademskog) osposobljavanja, kao i druge aspekte obrazovanja kao što su vrijednosti, osobni i društveni rast i razvoj, konceptualizirane pojmovima obrazovanja i odgoja za koje je teško pronaći odgovarajući engleski prijevod u međunarodnoj literaturi o obrazovanju. S obzirom na popularnost tih dvaju konstrukata u hrvatskoj javnosti, tim smo se dvjema dimenzijama ostvarivanja ciljeva koristili kao mjerama javne percepcije učinkovitosti škola. Budući da kritička literatura o obrazovanju vidi (i ne odobrava) usvajanje vještina potrebnih na tržištu rada kao jedini cilj obrazovanja (Nóvoa, 2013), tu smo dimenziju uključili kao relevantnu mjeru javne percepcije učinkovitosti škola. 
Razvili smo jednostavan upitnik koji se sastoji od sljedećih sastavnica: tri elementa kojima se mjeri percepcija učinkovitosti škola, tri elementa vezana uz percepciju relativnog položaja nacionalnog obrazovnog sustava unutar benchmarkinga međunarodnog obrazovanja, te devet elemenata koji služe kao mjera javnog povjerenja $\mathrm{u}$ institucije i aktere relevantne za obrazovni sustav. Za sve opisane jedinice koristili smo se standardnom, simetričnom i ekvidistantnom Likertovom skalom s pet stupnjeva (ne)slaganja s opisima jedinica. Javna percepcija tipične uloge školskih ravnatelja u hrvatskom obrazovnom sustavu procijenjena je s pomoću jedinstvene jedinice kojom se opisuje položaj obrazovnog menadžera kao: (a) neovisna menadžerska profesija, (b) politički položaj i (c) počasni položaj. Priroda ravnateljskog posla opisana je uz pomoć idealizirane dihotomije političke kontrole kojoj je suprotstavljen decentraliziran proces donošenja odluka od menadžerskih profesionalaca, kako ga opisuje OECD (2016). Treća dimenzija uvedena je na temelju kvalitativnog istraživanja provedenog u Hrvatskoj (Vican, Sorić i Radeka, 2016).

\section{Hipoteze istraživanja}

Ovdje predstavljeno istraživanje temelji se na sljedećim hipotezama:

H1. Javna interpretacija relativnog položaja pojedine zemlje unutar istraživanja benchmarkinga međunarodnog obrazovanja utječe na percepciju školskih ravnatelja kao menadžerske profesije.

H2. Povjerenje u relevantne društvene institucije utječe na percepciju školskih ravnatelja kao menadžerske profesije.

H3. Povjerenje u relevantne pojedinačne društvene aktere utječe na percepciju školskih ravnatelja kao menadžerske profesije.

H4. Percepcija cjelokupne učinkovitosti školstva pojedine zemlje oblikuje percepciju školskih ravnatelja kao menadžerske profesije.

\section{Empirijski rezultati}

Dvije prije opisane mjere (povjerenje u društvene institucije i pojedinačne aktere relevantne za obrazovanje i obrazovne institucije) sastoje se od pet, odnosno od četiri jedinice. Preliminarna provjera unutarnje valjanosti provedena je uz pomoć Cronbachova alfa koeficijenta s vrijednostima od 0,739 , odnosno 0,802 , koje bi se dalo opisati kao odgovarajuće za prilično rane stadije empirijskog istraživanja (Henson, 2001). Ljestvica koja mjeri učinkovitost obrazovanja i sastoji se od tri jedinice o kojima je prije bilo riječi, ima sličnu prihvatljivu vrijednost Cronbachove alfe u iznosu od 0,735. Opisni statistički podatci za neovisne varijable predstavljeni su u tablici 1.

\section{Tablica 1}

Nismo razvili jedinstvenu ljestvicu za mjerenje percepcije relativnog položaja unutar benchmarkinga međunarodnog obrazovanja, budući da je konceptualno teško ocijeniti relativnu usporedivost mjerenih jedinica. Nadalje, u nedostatku starijih 
empirijskih istraživanja odlučili smo se na istraživačku analizu triju jedinica uključenih u konstrukt. Koristili smo se dvodijelnim klasterskim postupkom, tj. hijerarhijskim klasterom kojemu je prethodio predklasterski algoritam. Najprije se koristio optimalan broj klastera (odabran s pomoću softvera za statističku obradu podataka), dobivenih primjenom log-izvjesnosti za mjerenje udaljenosti i Schwarz-Bayesova kriterija. Time je dobiveno sedam klastera, što se pokazalo kompliciranim za interpretaciju.

S fiksiranom brojkom od dva klastera kvaliteta klastera opada s dobre na zadovoljavajuću. Najvažniji faktori prognoze su stav obrazovnog sustava prema visokorazvijenim državama članicama Europske unije $(1,0)$, ostalim državama Europske unije $(0,30)$, kao i državama JIE $(0,11)$. Prvi klaster obuhvaća $51,3 \%$ slučajeva $(\mathrm{N}=303)$ i može se lako razumjeti kao položaj obrazovnog sustava jednak onome u većini najrazvijenijih država članica Europske unije, odnosni bolji od položaja obrazovnog sustava u ostalim državama članicama Europske unije, kao i državama JIE. Drugi klaster obuhvaća 48,7 \% slučajeva $(\mathrm{N}=288)$ i može se tumačiti kao položaj obrazovnog sustava koji je lošiji nego u državama članicama Europske unije, ali bolji nego u državama JIE. Varijabla klastera članstva koristila se u daljnjoj analizi za opisivanje tih dviju konfiguracija benchmarkinga međunarodnog obrazovanja, kako ih vidi hrvatska javnost.

Čak 47,7 \% hrvatskih ispitanika vjeruje da je položaj školskoga ravnatelja odraz politike, tj. izravne primjene obrazovne politike na razinu škole (tablica 2). To je u potpunoj opreci s preporukama razvoja ravnateljstva kao neovisne menadžerske profesije (OECD, 2016). Tek trećina ispitanika zanimanje školskoga ravnatelja vidi kao neovisno menadžersko zanimanje, a njih $12,5 \%$ vidi ga kao počasno zvanje, uglavnom važno za starije učitelje koji se spremaju u mirovinu.

\section{Tablica 2}

Budući da je cilj ovog istraživanja bio identificirati čimbenike koji pridonose percepciji ravnatelja kao neovisnih menadžerskih profesionalaca, zavisna je varijabla pretvorena u dihotomnu (točno/netočno) varijablu, koju se može primijeniti u analizi uz pomoć binarne logističke regresije. Svjesni smo toga da bi takav postupak mogao dovesti do pojave određenih odstupanja u rezultatima istraživanja, koji bi uz pomoć složene statističke analize trebalo istražiti u budućim radovima.

Budući da njihova distribucija odstupa od pretpostavljene normalnosti (provjerene s pomoću Kolmogorov-Smirnovljeva testa), bivarijatna korelacijska matrica za relevantne varijable (tablica 3) dobivena je primjenom neparametrijskih (Spearmanovih) indikatora. Iako vrlo značajne, sve su korelacije slabe do umjerene snage, što je opravdalo daljnju analizu.

Tablica 3

Kao što je prije istaknuto, binarna logistička regresija provedena je s ciljem identificiranja faktora koji pridonose percepciji ravnateljstva kao profesije među hrvatskom javnosti. Pretpostavka linearnih odnosa između prediktora i logističke 
vjerojatnosti zavisne varijable provjerena je na temelju preporuka Boxa i Tidwella (1962). Bonferronijeva korekcija primijenjena je na 11 uvjeta, što rezultira statističkim značajem $\mathrm{u}$ iznosu od $\mathrm{p}<, 0045$, primijenjenim sa svrhom prihvaćanja pretpostavke o linearnosti. U model su uključene i tri dodatne kontrolne varijable: rod, stupanj visokog obrazovanja i status roditelja (barem jednog) malodobnog djeteta (ili djece) koje živi u istom kućanstvu. Devet rezidualnih opažanja, s vrijednostima većim od dvaju standardnih devijacija, isključeno je iz analize.

Analizirani model $\left(\chi^{2}(7)=97,41\right)$ je značajan, a razlika između temeljnog modela (u koji je uključena samo konstanta) i istraživačkog modela iznimno je značajna ( $p$ $<0,001)$. Postotak ispravno klasificiranih slučajeva iznosi $70,4 \%$, pri čemu model objašnjava 21,4 \% varijance u percepciji ravnateljstva (prema indikatoru Nagelkerke $\mathrm{R}^{2}$ ). Statistički značaj prediktorskih varijabli predstavljen je u tablici 4.

\section{Tablica 4}

Povjerenje u institucije važne za obrazovanje nije se pokazalo kao značajan faktor prognoze percepcije ravnateljstva kao menadžerske profesije. Taj rezultat u skladu je s prijedlozima iznesenima u istraživanju koje su proveli Pavičić, Alfirević i Bežovan (2017), kao i sociološkim istraživanjima koja upućuju na nizak stupanj povjerenja u institucije, koje unutar regije JIE zamjenjuju neformalne i obiteljske veze (Pichler i Wallace, 2007). Povjerenje u relevantne individualne aktere koji bi mogli utjecati na obrazovni sustav i njegov razvoj vlastitim 'herojskim' postupcima i transformacijskim sposobnostima pokazalo se kao značajan faktor prognoze prihvaćanja ravnateljstva kao profesije $(\mathrm{p}<0,01)$. Pouzdavanje u pojedinačne društvene aktere (umjesto potvrđenih institucija) može se pripisati specifičnim društvenim karakteristikama regije JIE. Te su karakteristike usporedive s rezultatima istraživanja o kolektivnom djelovanju u lokalnim zajednicama (Pavičić, Alfirević i Bežovan, 2017). Opseg učinka prilično je dojmljiv, budući da uvećanje jedne relativne jedinice javnog povjerenja $\mathrm{u}$ individualne društvene aktere važne za obrazovanje (mjerene ljestvicom od pet jedinica) uvećava vjerojatnost percipiranja ravnateljstva kao neovisne menadžerske profesije čak 3,12 puta.

Isti je zaključak primjenjiv na percepciju učinkovitosti škola, koja pokazuje da ne samo da 'ispravne' prakse obrazovnog rukovodstva i menadžmenta rezultiraju uvećanom učinkovitošću, već i da je spomenuta veza dvosmjerna. Naime, postoji značajan učinak doživljene cjelokupne učinkovitosti kao faktora prognoze menadžerske profesionalizacije: sa svakom jedinicom uvećanja javne percepcije školske učinkovitosti (mjerene ljestvicom od pet stupnjeva) vjerojatnost da će se ravnateljstvo doživjeti kao neovisna menadžerska profesija uvećava se 1,70 puta. Za učinkovite se škole stoga pretpostavlja da ih vode ravnatelji javno prepoznati kao menadžeri.

Zanimljivo je da se percepcija pokazatelja u međunarodnom obrazovnom benchmarkingu nije pokazala kao relevantna prediktorska varijabla. To bismo mogli 
objasniti uz pomoć prijašnjeg istraživanja koje je pokazalo da javna percepcija takvih međunarodnih istraživanja nije nužno ispravna, barem ne u slučaju Hrvatske (Vican, Alfirević, i Pavičić, 2017). Zanimljivo je i da se ni jedna od uključenih kontrolnih varijabli nije pokazala značajnim faktorom prognoze percepcije ravnateljstva kao menadžerske karijere, što upućuje na zaključak da demografske varijable možda nemaju značajan utjecaj na percepciju profesije ravnatelja.

\section{Zaključak i implikacije za politiku}

Od četiri hipoteze istraživanja samo su se povjerenje u pojedinačne aktere (hipoteza H2) i percepcija učinkovitosti školstva u pojedinoj državi (hipoteza H4) pokazale značajnim faktorima prognoze javne percepcije profesije ravnatelja u Hrvatskoj. Ostala dva faktora prognoze identificirana hipotezama $\mathrm{H} 1$ (povjerenje u društvene institucije) i H3 (relativni položaj pojedine države u studijama međunarodnog benchmarkinga obrazovanja) nisu se pokazala empirijski značajnima.

Dihotomija povjerenja u institucije i društvene strukture s jedne, te pojedine aktere s kojima zainteresirani dionici imaju osobne, obiteljske ili društvene poveznice s druge strane, dobro je istražena sociološka tema u regiji JIE. Čini se da su rezultati koji određuju oblikovanje društvenog kapitala, funkcioniranje civilnoga društva, te društveno i djelovanje unutar zajednice, primjenjivi i na područje obrazovne politike. Iako bi dobiveni rezultati mogli biti empirijski relevantni za istraživanje obrazovanja i zanimljivi za istraživače menadžmenta koje zanima primjena njihovih teorija na područje menadžmenta i rukovodstva u obrazovanju, radi se o temi koja nije osobito zanimljiva.

Drugi faktor prognoze za koji se uspostavilo da je empirijski relevantan za nacionalno reprezentativan uzorak hrvatskih domaćinstava nudi sasvim drugačiju sliku. Spomenuti faktor vezan je uz društvenu konstrukciju menadžerske profesije i koncepte učinkovitosti o kojima je već bilo riječi u donekle povezanom području neprofitnog menadžmenta. Poveznicu između profesionalnog školskog menadžmenta (ravnateljstva) i uspjeha u višem obrazovanju (učinkovitosti) lako je razumjeti, ali i obrnuti.

Naime, zbog prilično velikog jaza između javnog mišljenja i rezultata studija međunarodnog benchmarkinga (kakve predlažu Vican, Alfirević i Pavičić, 2017), za koje se vjeruje da predstavljaju objektivni faktor prognoze djelovanja u obrazovanju, školska bi se učinkovitost mogla pokazati kao društveni konstrukt. Čini se da dobiveni empirijski rezultati ovog istraživanja, koje odbacuje empirijski značaj međunarodnog benchmarkinga kao čimbenik javne percepcije profesionalizacije ravnatelja, potvrđuju takvo zapažanje.

U našem uzorku, društvena percepcija obrazovnih institucija (ili praksi) kao visoko učinkovitih, dovodi do priznavanje/konstrukcije ravnateljstva kao menadžerske profesije. Javna percepcija stoga djeluje u oba smjera: percepcija 'ispravnih' praksi rezultira percepcijom učinkovitosti i obrnuto. Buduća bi istraživanja trebala pokazati 
postoje li neki dodatni konstrukti koji moderiraju ili posreduju takav odnos, te da li sam učinak s vremenom varira.

Dobiveni rezultati sugeriraju zanimljive implikacije za javnu politiku. Važnost društvenog povjerenja i njegov utjecaj na javne politike utemeljene na mrežama osobnih veza i mišljenja (umjesto na objektivnim procesima koji se oslanjaju na dokaze), još jednom se potvrđuje na primjeru jugoistočne Europe (JIE). Još je zanimljiviji novi obrazac javne percepcije i kreiranja politika koji bi mogli primijeniti akteri politika i zainteresirani dionici u JIE. Radi se o konstrukciji pozitivnih narativa i primjera 'dobrih praksi' na razinama pojedinaca i institucija, koje valja usmjeriti relevantnim javnim politikama. Takve preporuke ne bi trebalo tumačiti kao izraz podrške problematičnih praksi, koja kreiranje javnih politika svodi na svojevrsnu 'majstoriju' na polju javnih odnosa kakvu bi mogli izvesti niskopozicionirani zaposlenici u javnim službama, pa čak i neke razine vlada u regiji. Umjesto toga, spomenutim je preporukama cilj ojačati lokalnu i/li regionalnu sposobnost djelovanja i donošenja političkih odluka koje imaju pozitivne političke posljedice. To uključuje potrebu da političke elite i politički akteri u malim državama preuzmu istinsku odgovornost za njihove postupke, što se lako može izbjeći praznom retorikom 'depolitizacije' procesa kreiranja politika. Stručnjaci i stručni odbori mogu biti korisni u donošenju politika te benchmarkingu i primjeni preporuka Europske Unije, no ne mogu nadomjestiti viziju i predanost onih koji kreiraju politike. U konačnici, srca i umove javnosti nije moguće pridobiti 'tehnokratskim' narativima, već dokazima 'dobrih praksi' na lokalnoj i regionalnoj razini koje se sistemski odobrava i institucionalizira. To nadalje valja povezati sa sposobnostima institucionalne izgradnje i pokušajem stvaranja sustava pozitivnih povratnih informacija koje naglašavaju međusobne poveznice između razvoja lokalnih resursa i dijeljenja pozitivnih lokalnih narativa.

Osim toga, budući da su prakse na polju odnosa s javnošću u Hrvatskoj visoko personalizirane i pod utjecajem osobnih veza (Taylor, 2004), konstrukcija negativno intoniranih narativa i medijskih utjecaja nameće se kao realistična opcija za neke aktere politika koji teže javnom utjecaju. Naše preporuke također se doimaju kao dobra protumjera takvim 'odmetnutim' pokušajima kreiranja politika. Također se nadamo da će buduća istraživanja malih država u regiji JIE i izvan nje pridonijeti generalizaciji naših rezultata, koji bi političkim elitama i onima koji kreiraju politike mogli ponuditi realistične mogućnosti kreiranja i održavanja uspješnih obrazovnih politika.

\section{Napomena}

Empirijsko istraživanje provedeno za potrebe ovoga rada realizirano je uz financijsku pomoć Ministarstva znanosti i obrazovanja Republike Hrvatske, u okviru Znanstvenog centra izvrsnosti za školsku efektivnost i menadžment. 